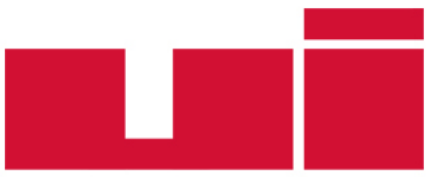

ULLUSLARARASIILIŞKiLER

Yayın ilkeleri, izinler ve abonelik hakkında ayrıntılı bilgi:

E-mail: bilgi@uidergisi.com.tr

Web: www.uidergisi.com.tr

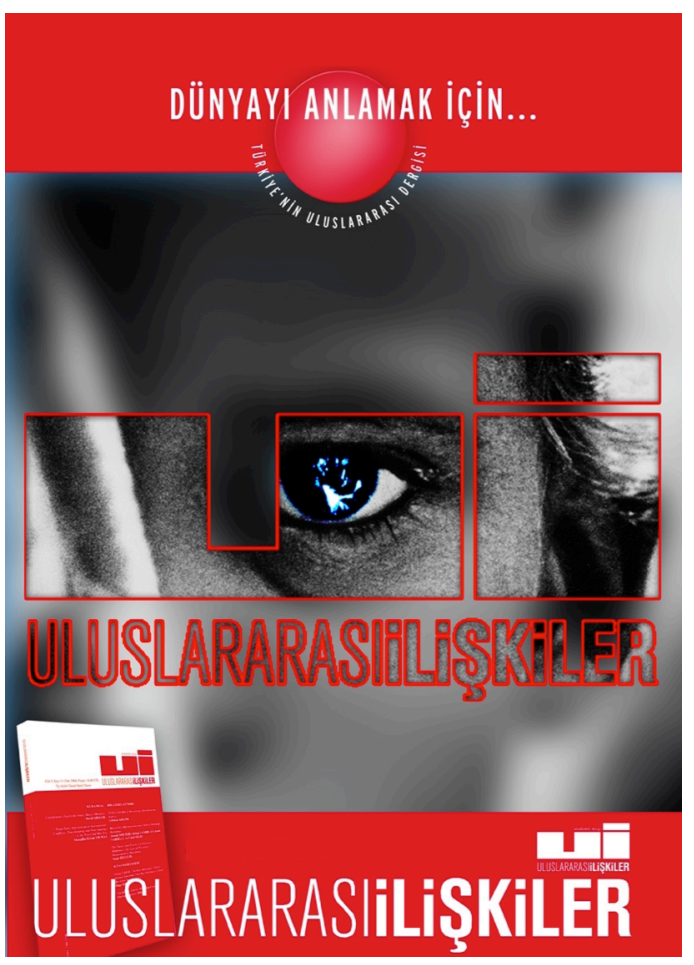

\title{
Rejim Teorileri
}

Sevilay Z. AKSOY*

* Yrd. Doç. Dr., Dokuz Eylül Üniversitesi, Uluslararası İlişkiler Bölümü

Bu makaleye atıf için: Aksoy, Sevilay Z., "Rejim Teorileri", Uluslararası Illişkiler, Cilt 12, Sayı 46, s. 57-77.

Bu makalenin tüm hakları Uluslararası İlişkiler Konseyi Derneği’ne aittir. Önceden yazılı izin alınmadan hiç bir iletişim, kopyalama ya da yayın sistemi kullanılarak yeniden yayımlanamaz, çoğaltılamaz, dağıtılamaz, satılamaz veya herhangi bir şekilde kamunun ücretli/ücretsiz kullanımına sunulamaz. Akademik ve haber amaçlı kısa alıntılar bu kuralın dışındadır.

Aksi belirtilmediği sürece Uluslararası İlişkiler'de yayınlanan yazılarda belirtilen fikirler yalnızca yazarına/yazarlarına aittir. UİK Derneğini, editörleri ve diğer yazarları bağlamaz.

\section{Uluslararası İlişkiler Konseyi Derneği | Uluslararası İlişkiler Dergisi}

Web: www.uidergisi.com.tr| E- Posta: bilgi@uidergisi.com.tr 


\title{
Rejim Teorileri
}

\section{Sevilay Z. AKSOY}

Yrd. Doç. Dr., Uluslararası İlişkiler Bölümü, Dokuz Eylül Üniversitesi, İzmir. E-posta: sevilay.aksoy@deu.edu.tr.

\section{ÖZET}

$\mathrm{Bu}$ makale uluslararası ilişkiler kuramında devletler arası işbirliğinin uluslararası sistemin anarşik yapısına rağmen mümkün olduğunu iddia eden ve bu iddiasıyla gerçekçi kuramın öne çıkardığı "kaçınılmaz çatışma” savını sorgulayan rejim teorilerini incelemeyi amaçlamaktadır. Bu bağlamda rejim kavramı ve buna dair ontolojik ve epistemolojik tartışmalar ile rejim kuramının çoğul yapısı içinde çıkar, güç ve bilgi bazlı yaklaşımlar ele alınacaktır.

Anahtar Kelimeler: Sistem, Rejim, Rejim Teorileri, Yeni-Liberal Kuram

\section{Regime Theories}

\begin{abstract}
This article aims to examine the regime theories, which put a claim on the possibility of interstate cooperation notwithstanding the anarchic nature of international system, and thus, which call into question the "inevitability of the conflict" as emphasized by the realist theory. In this context, the concept of regime, the ontological and epistemological debates that pertain to it, and the interest, power and knowledge based approaches that reflect the plural nature of the regime theory will be successively analyzed.
\end{abstract}

Keywords: System, Regime, Regime Theories, Neo-Liberal Theory 


\section{Giriş}

Uluslararası sistemde devletlerin iç düzenindekine benzer bağlayıcı kararlar alan ve uygulayan merkezi bir otoritenin olmayışı gerçekçi yaklaşımlar tarafından anarşik bir yapı olarak tanımlanmıştır. ${ }^{1}$ Uluslararası İlişkiler (UI) disiplininin önde gelen kuramlarından gerçekçi kurama göre anarşik yapının devletlerin dış politika davranışına etkisi doğrudan ve nettir: Devletler kendi güvenlik ve refahlarını bireysel olarak sağlamak zorunda olup, bu hedef doğrultusunda mücadele ederlerken aralarında çıkar çatışması yaşanma riski yakın ve büyüktür. ${ }^{2}$ Buna göre devletlerin niyetlerine dair hâkim olan varoluşsal belirsizlik, anarşik ortamda işbirliğinden ziyade çatışmayı beslemektedir. Niyetlere ilişkin en kötü senaryo üzerinden hareket eden devletler arasında güvenlik ikilemi ve benzeri durumların oluşması kaçınılmazdır; çünkü iyi niyete güvenerek hareket etme, yaptırım gücüne sahip merkezi bir otorite boşluğunda devletin güvenlik ve bekasını tehlikeye atabilir. ${ }^{3}$

Peki, bu durumda var olan ve örnekleri güvenlik dâhil çeşitli alanlarda hızla çoğalan devletler arası işbirliği örneklerini nasıl açılayabiliriz? 1970'lerden itibaren Uİ disiplininde kendine yer edinen rejim teorilerinin ana sorunsalı bu soru olmuştur. Burada söz konusu edilen işbirliği, norm ve kurallara dayalı işbirliği olup, bu konunun disiplinde ele alınması eskilere dayansa da (özellikle uluslararası hukuk geleneği, İngiliz Okulu ve liberal kuram), konunun çeşitli yönleriyle sistematik ve test edilebilir hipotezlere dayalı olarak incelenmesi rejim teorisi yoluyla olmuştur. ${ }^{4}$

Karşılıklı bağımlılığın küreselleşme ile arttığı uluslararası ortamda kahvenin üretimi, dağıtımı ve pazarlanmasından nükleer silahların azaltılmasına kadar birbirinden çok farklı alanlarda devletlerin birbirleriyle kurala dayalı işbirliğine girdiklerine tanık olmaktayız. Rejim teorisi bunun nasıl anarşik bir ortamda mümkün olduğu sorusuna rejimlerin kurulması, sürdürülmesi ve etkinliği üzerinden cevap aramaktadır. Bu konularda rejim teorisini çoğul kılacak şekilde birbirinden farklı argümanlar ortaya konmuş olup, bu durum Uİ disiplinindeki kuramların uluslararası işbirliği konusuna farklı yaklaşımlarından kaynaklanmaktadır. Sonuçta rejim teorisi çatısı altında gerçekçi, liberal ve sosyal inşacı kuramların ilgili varsayımlarını baz alan üç temel yaklaşım ortaya çıkmıştır. Literatürde bu yaklaşımlar güç-bazlı, çıkar-bazlı ve bilgi-bazlı rejim teorileri olarak ifade edilmektedir. ${ }^{5} \mathrm{Bu}$ makalede söz konusu teoriler rejim kavramının ontolojik ve epistemolojik analizini takiben ayrı ayrı ele alınacaktır.

\section{Rejim Kavramı: Ontolojik ve Epistemolojik Konular}

Uluslararası İlişkiler disiplininde rejim kavramının kapsamlı ve sistematik bir şekilde incelenmesi, İkinci Dünya Savaşı sonrasında Amerika Birleşik Devletleri (ABD) öncülüğünde kurulan uluslararası ticaret ve finans rejimlerinin, ABD'nin başat (hegemon) gücünün 1970'lerin sonuna doğru

1 Örneğin bkz., Kenneth N. Waltz, Theory of International Politics, Reading, Mass., Addison-Wesley, 1979, s.88-89.

2 John J. Mearsheimer, “The False Promise of International Institutions”, International Security, Cilt 19, No.3, 1994/1995, s.10-12.

3 Ken Booth ve Nicholas J. Wheeler, The Security Dilemma: Fear, Cooperation and Trust in World Politics, Hampshire, Palgrave Macmillan, 2008, s.1-10.

4 Andrew Hurrell, "International Society and the Study of Regimes: A Reflective Approach", Volker Rittberger (der.), Regime Theory and International Relations, Oxford, Clarendon Press, 1995, s.50-54.

5 Kapsamlı ve sistematik bir analiz için bkz., Andreas Hasenclever, Peter Mayer ve Volker Rittberger, Theories of International Regimes, Cambridge, Cambridge University Press, 1997. 
düşüşe geçmesiyle beraber yeniden yapılandırılmalarına ilişkin olarak gündeme gelmiştir. Güç ve çıkar ile norm ve kurallar arasındaki ilişki ve başat gücün zayıflamasının veya uluslararası güç dağılımındaki değişimin hâlihazırdaki uluslararası işbirliklerine etkisi gibi konular bu tarihten sonra yeniden ve sistematik bir şekilde ele alınmıştır. 1982 yılında International Organization dergisinde yayımlanan ${ }^{6}$ ve sonradan Stephen D. Krasner'in editörlüğ̈̈nü yaptığı Uluslararası Rejimler kitabın$\mathrm{da}^{7}$ toplanan makaleler bunun öncüsü olarak görülebilir. Söz konusu kitap ve takip eden çalışmalarda uluslararası rejim kavramına farklı tanımlar getirilmiş olsa da, Krasner'ın ortaya koyduğu tanım genel kabul görmüş ve sonraki ontolojik ve epistemolojik tartışmalar çoğu kez bu tanım üzerinden yürütülmüştür.

Krasner, uluslararası rejimi "uluslararası ilişkilerin belli bir konu alanına ilişkin olarak aktörlerin beklentilerinin etrafinda örtüştüğü gizli veya açı prensip, norm, kural ve karar alma prosedürleri bütünü" olarak tanımlamıştır. ${ }^{8}$ Diğer bir ifadeyle, herhangi bir uluslararası sorunun ortaya konması ve çözümüne ilişkin olarak devletlerin üzerinde resmi veya gayri resmi olarak anlaşmaya vardıkları prensip, norm, kural ve karar alma mekanizmaları rejim olarak adlandırılmıştır. Kimi yazarlar bu tanımdaki kavram kargaşasına dikkat çekerken (prensip, norm ve kural arasındaki farkın her durumda belirgin olmaması), ${ }^{9}$ diğerleri gizli veya ima edilen kurallardan ziyade sadece açık bir yazılı antlaşmaya dayanan ve devletlerin davranışları üzerinde etki yaratan rejimlerin dikkate alınmasını önermişlerdir. ${ }^{10}$ Bu bağlamda özellikle davranışsal sonuçlar doğurmayan kural ve/veya anlaşmaların rejim kapsamında değerlendirilmemesi gerektiğini savunanlar olmuştur. Bunlardan bazıları daha katı bir tutum izlerken, ${ }^{11}$ bazıları daha esnek bir tutum sergilemiştir.

Rejimleri sosyal kurum çerçevesi içinde ele alan Oran Young ikinciye örnek olarak gösterilebilir. Rejim teorisini giderek artan ve çok boyutlu hale gelen çevresel sorunlara uygulamasıyla tanınan Young'a göre rejim, birtakım kural, konvansiyon veya antlaşmalar ile bunlara bağlı rolleri icra eden aktörlerden oluşan uluslararası bir kurumdur. ${ }^{12}$ Her ne kadar literatürde kurum ve örgüt kavramlarını eş anlamlı kullanma eğilimi varsa da, Young bunun her zaman için doğru olmadığını, herhangi bir örgütün eşlik etmediği çeşitli rejim/kurumların da mevcut olduğunu dile getirmiştir. ${ }^{13}$ Young'un tanımında kurallar ve bu kurallara bağlı sorumluluklarını yerine getiren aktörlere yapılan gönderme, ister istemez kurallara bağlı hareket etmenin kurumun varlığına yönelik güçlü bir gösterge olduğunu ortaya

6 International Organization, Cilt 36, No.2, 1982.

7 Stephen D. Krasner (der.), International Regimes, Ithaca, Cornell University Press, 1983.

8 Stephen D. Krasner, “Structural Causes and Regime Consequences: Regimes as Intervening Variables”, Krasner (der.), International Regimes, s.186.

9 Krasner, rejim tanımındaki unsurlara şu şekilde açıllık getirmiştir: Prensipler, gerçeğe, nedenselliğe ve doğruluğa ilişkin görüş ve inançlardır; normlar, hak ve sorumlulukları ifade eden davranış biçimidir; kurallar, eylemi düzenleyen belirli önerme veya yasaklamalardır; karar alma prosedürleri ise ortak karar alma ve uygulamayı mümkün kılan mekanizmalardır. Bkz. Krasner, "Structural Causes and Regime Consequences", s.186. Oran R. Young, hem orijinal tanımdaki hem de Krasner’ın getirdiği açıklamadaki yeni unsurların muğlak olduğunu, gerçek hayatta çoğu kez birbirleriyle örtüştügünü, daha da önemlisi söz konusu tanımın "kavramsal olarak zayıf” olduğunu ve muğlaklığı giderecek şekilde daha geniş bir fikir sistematiğine bağlanmadığını ifade etmiştir, bkz., Oran R. Young, "International Regimes: Toward a New Theory of Institutions”, World Politics, Cilt 39, No.1, 1986, s.106. Ayrıca bkz., Stephen Haggard ve Beth A. Simmons, “Theories of International Regimes", International Organization, Cilt 41, No.3, 1987, s.493-496.

10 Volker Rittberger, "Research on International Regimes in Germany: The Adaptive Internalization of an American Social Science Concept”, Rittberger (der.), Regime Theory, s.9-10.

11 Ibid.

12 Oran R. Young, International Cooperation: Building Regimes for Natural Resources and the Environment, Ithaca, Cornell University Press, 1989, s.12-13.

13 Ibid., s.31-37. 
koymaktadır. Fakat Young, her sosyal kurumda olduğu gibi, rejimlerde de ihlâllere rastlanabileceğini, önemli olanın ihlâllerin yaygınlık kazanıp kazanmadıklarının araştırılması olduğunu vurgulamıştır. ${ }^{14}$

Yeni-liberal kuramın ileri gelen çalışanlarından Robert Keohane ise rejim etkinliğinin ayrı bir değişken olarak ele alınması gerektiğini ve bu sebeple rejim tespitinde davranışsal etki aramanın (kurallara uyma veya ihlâl) yerinde olmadığını savunmuştur. ${ }^{15}$ Keohane'nin rejim tanımında ortaya çıkan unsurlar, devletler arasında imzalanan antlaşmaların resmi olması ve devletlerin bu antlaşmalara tam olarak uymasalar bile, onların geçerli olduklarını kabul etmelerini gerektirir. ${ }^{16}$

Gizli veya ima edilen kural ve antlaşmalar ile rejim etkinliğini devreden çıkaran Keohane’nin tanımı her ne kadar orta yol gibi gözükse de, konuya sosyal inşacı kuram açısından yaklaşanlar bu tanımin rejimlerin özneler arası (intersubjective) ontolojisini göz ardı ettiğini ve dolayısıyla yorumsamacı (interpretivist) epistemolojiyi saf dışı bıraktığını belirtmişlerdir. Bu kuramın Alman ekolünün temsilcisi Friedrich Kratochwil ve Amerikalı çalışanlarından John G. Ruggie, rejimlerin salt yazılı antlaşmalara indirgenemeyecek özneler arası bir ontolojisi olduğunu ve Krasner'ın tanımında yer alan "devletlerin beklentilerinin örtüşmesi” unsurunun da aslında bu duruma işaret ettiğine dikkat çekmişlerdir. Bir rejimin oluşup oluşmadığı veya halen varlığını sürdürüp sürdürmediğine ilişkin sorulara Keohane ve diğerlerinin destekledikleri pozitivist epistemoloji ile yanıt bulunamayacağını iddia eden Kratochwil ve Ruggie'ye göre, devletlerin aralarında ima veya imza yoluyla vardıkları antlaşmalara ilişkin kullandıkları söylemin/dilin analizi bu konunun anlaşılmasında daha yerinde ve geçerlidir. ${ }^{17}$ Dolayısıyla, yorumsamacı epistemolojiyi baz alanlar salt kural ihlâllerine bakarak rejimin zayıfladığını veya çökmek üzere olduğunu söylemek yerine, devletin ihlâl/leri yaparken kullandığı dile önem vermişlerdir. Bu bağlamda, edilen özürler, talep edilen ayrıcalıklar, haklılaştırmalar ve benzeri edimler daha sağlıklı analiz verileri olarak kabul edilmiştir. ${ }^{18}$

Kısacası, literatürde rejimin kavramsallaştırılması üzerine ontolojik ve epistemolojik bir görüş birliği yoktur. Rejim kuramının kimi çalışanları sadece gözlenebilen, somut ve/veya yazılı kural ve antlaşmaları rejim kapsamında değerlendirirken, diğerleri yazılı veya resmi olmasa da devletlerin davranışlarını karşılıklı olarak düzenleyen ve ima yoluyla veya gayri resmi olarak belirlenmiş norm, kural ve/veya anlaşmaları da bu kapsama dâhil etmektedirler. Kimileri devletlerin davranışlarında değişikliğe yol açmayan anlaşma veya konvansiyonları rejim olarak nitelendirmeye yanaşmazken, kimileri davranışsal sonucu rejim tanımının bir parçası olarak değil, ayrı bir değişkeni olarak görme eğilimindedir. Davranışsal etkinin, yani kimilerine göre rejim varlığının kimilerine göre ise rejim etkinliğinin, belirlenmesi hakkında da bir uzlaşı olmayıp, akademisyenlerin farklı epistemolojik duruşlarına bağlı olarak pozitivist veya yorumsamacı yöntemler tercih ettikleri görülmektedir.

\section{Rejim Teorileri}

Uluslararası alanda devletlerin bağımsız hareket etmeleri halinde optimal veya en uygun şekilde çözüme kavuşturamayacakları ve sayıları giderek artan pek çok sorun mevcuttur. Rejim, devletlerin ortak

14 Ibid., s.70-71.

15 Robert O. Keohane, “The Analysis of International Regimes: Towards a European-American Research Programme”, Rittberger (der.), Regime Theory, s.27-28.

16 Ibid., s.28.

17 Friedrich Kratochwil ve John Gerard Ruggie, "International Organization: A State of the Art on an Art of the State", International Organization, Cilt 40, No.4, 1986, s.764-766. Ayrica bkz., Hurrell, "International Society and the Study of Regimes”, s.64; Friedrich Kratochwil, "Contract and Regimes: Do Issue Specificity and Variations of Formality Matter?", Rittberger (der.), Regime Theory, s.84-93.

18 Kratochwil ve Ruggie, “International Organization”, s. 67-768. 
çıkarlarını gerçekleştirmek veya ortak olarak istenilmeyen durumları önlemek için birlikte hareket etmelerini sağlayan veya en azından kolaylaştıran bir kurumdur. ${ }^{19}$ UI disiplininin farklı okullarını temsil eden kuramcıları, çözüm bekleyen ulus-aşırı sorunların varlığını kabul etmekle birlikte, ortak hareket etmenin veya uluslararası işbirliğinin mümkün olup olmadığı, önündeki engellerin neler olduğu ve bunların aşılabilirliği konularında farklı ve her zaman birbiriyle uzlaştırılamayan argümanlar ortaya koymuşlardır. Aşağıda bu argümanlar ele alınıp incelenecektir.

\section{Yeni-Liberal Kurumsalcı veya Çıkar-Bazlı Yaklaşım}

Anarşik uluslararası sistemde devletler arası işbirliği olasılığının mümkün olduğunu savunan ve bu fikrin öncüsü konumundaki kuram yeni-liberal kurumsalcılıktır. Bu kuram uluslararası işbirliği fikrine en mesafeli yaklaşan gerçekçi kuramın ve özellikle onun "yeni” versiyonunun bazı temel varsayımlarını paylaşsa da (uluslararası sistemin anarşik yapıya sahip olması ve devletin temel aktör olarak kabulü gibi), işbirliği konusundaki varsayımları ona farklı bir kuram özelliği kazandırmıştır. Yeni-liberallere göre devletler akılcı egoist aktörler olup, davranışlarını belirleyen temel mantık araçsal (instrumentalist) mantıktır. Bu mantığa uygun davranan, daha doğrusu davranması beklenen devlet adamları, fayda-zarar hesabı yapıp, ülkelerine ulusal çıkar açısından en fazla fayda sağlayacak politikaları seçmek ve uygulamak durumundadırlar. Bu bağlamda, eğer diğer devletlerle yapılacak herhangi bir işbirliği söz konusu devleti eskisinden mutlak olarak daha kazançlı (absolute gains) bir konuma getirecekse liberaller buna olumlu yaklaşılması gerektiğini savunurlar. Bu son nokta, yani devletin kazancını diğer devlet/lerin kazancından bağımsız olarak hesaplaması ve başkalarının kazancına kayıtsız kalması, aşağıda da açılklanacağı gibi, yeni-liberalleri gerçekçi kuramcılardan ayıran en temel farklardan biridir. ${ }^{20}$

Yeni-liberaller, devletlerin işbirliği yapmak için ortak çıkarlara sahip olması gerektiğini varsayarlar. Burada ortak çıkarlardan kastedilen çıkarların uyumu veya tamamen benzeşmesi değildir; işbirliği, bir sorunun çözümüne ilişkin olarak çelişen ve birbirini tamamlayan çıkarlar demeti söz konusu olduğunda anlam kazanır ve gerçekleşebilir. ${ }^{21}$ Yeni-liberaller, devletlerin bağımsız hareket etmeleri halinde hepsi için aynı anda optimal olmayan ve uzun vadede zararlarına olabilecek, ortak hareket ettiklerinde ise bu durumun tersine çevrilebildiği durumları tasvir etmek için mikro-iktisatta geliştirilen oyun kuramlarından yararlanmışlardır. ${ }^{22}$ Çeşitli çıkar çatışmalarını ve çözümlemelerini resmeden bu modeller arasında siyaset bilimcilerin en çok başvurdukları ve yeni-liberaller tarafından da rejimlerin gerekliliğini ortaya koymak için kullanılanı "mahkûm ikilemi”dir (the prisoner's dilemma). Söz konusu oyunda aralarında hiçbir iletişim olmayan iki aktörün bağımsız ve ortak hareket etme kararı verdiklerinde elde edecekleri sonuçlar varsayılmıştır. Buna göre aktörlerden biri işbirliğine yanaştığı ve diğeri aksi yönde davrandığında, işbirliğine yanaşmayan en çok kazanç elde eden, diğeri en çok kaybeden taraf olacaktır. İkisinin de işbirliği yapmadığı durum, her ikisinin de minimum kazanç elde edeceği durumdur. Her ikisi de işbirliği yönünde karar alırsa, orta derecede eşit kazançlı çıkacaklardır. Aralarında hiçbir iletişim olmayan ve dolayısıyla karşı tarafın vereceği karardan emin olunamadığı güvensizlik ortamında, her bir aktör açısından en kazançlı durum ilk olasılık gibi gözükmektedir. Buna karşılık,

19 Arthur A. Stein, “Coordination and Collaboration: Regimes in an Anarchic World”, International Organization, Cilt 36, No.2, 1982, s.304.

20 Hasenclever vd., Theories, s.23, 26.

21 Robert O. Keohane, After Hegemony: Cooperation and Discord in the World Political Economy, Princeton, Princeton University Press, 1984, s. 51-54; Stein, “Coordination and Collaboration”, s.301-302.

22 Farklı oyun kuramlarının rejim teorisine uygulanabilirliği konusunda bkz., Andrew Kydd ve Duncan Snidal, "Progress in Game-Theoretical Analysis of International Regimes", Rittberger (der.), Regime Theory, s.112-135. 
oyunun gerçek hayatta birden fazla oynandığı ve dolayısıyla aktörlerin birbirlerinin tercihlerinden zaman içinde haberdar olup, daha bilinçli karar verebilecekleri dikkate alındığında, işbirliği kararı uzun vadede tüm aktörler açısından en optimal olanıdır. ${ }^{23}$

Yeni-liberaller uluslararası alanda benzer şekilde kolektif varlıkları sağlamanın yolunun işbirliği yapmaktan geçtiğini ve rejimlerin de bunun için faydalı bir araç olduğunu savunurlar. Buna İkinci Dünya Savaşı sonrası kurulan serbest ticaret rejimi, ortak güvenliği sağlamaya yönelik oluşturulan güvenlik rejimleri ve ortak çevre alanlarının yok olmasını önlemek amacıyla kurulan çevre rejimleri örnek olarak gösterilmiştir. ${ }^{24}$ Söz konusu alanlarda devletlerin bireysel olarak en kazançlı yolu seçmeleri (örneğin, korumacı ticaret önlemleri alma, aşırı silahlanma ve çevresel kaynakları aşırı tüketmek) kısa vadede en rasyonel tercih gibi gözükse de, uzun vadede tüm aktörlerin benzer politikaları izlemeleri hepsi için istenilmeyen sonuçlar doğuracaktır (uluslararası ticaretin çökmese bile gerilemesiyle ulusal gelirlerin azalması, silahlanmanın güvenlik ikilemine dönüşmesi ve belki de savaşlara yol açması ile çevresel kaynakların tükenmesi gibi). ${ }^{25}$ Yeni-liberallere göre, bu tür istenilmeyen durumların önüne geçmek ve toplu faydayı sağlamak için ortak hareket etmek ve bunun içinde işbirliğinin önündeki temel engel olan güvensizliği bertaraf etmek gerekir.

Uluslararası işbirliği, devletlerin niyetlerine ilişkin belirsizliği azaltıcı araçlarla mümkün olabilir ki bu bağlamda yeni-liberallerin öne sürdükleri çözüm önerisi rejimdir. Yeni-liberaller, devletleri işbirliğine girmekten alıkoyan asıl sebebin ortaklarının bireysel maksimum kazanç elde etmek amacıyla kendilerini aldatması korkusu olduğunu iddia ederler. Yani bir devletin karşı tarafın iyi niyetli işbirliği çabalarını sömürerek bunu bireysel kazanca dönüştürmeye çalışması işbirliğinin önündeki temel engeldir. Örneğin, güvenlik ikilemini aşma amacıyla savunmaya yönelik silahların arttırılıp, saldırı amaçlı silahların azaltıldığı bir ortamda, bu amacı paylaşır gibi gözüküp saldırı silahlarını imha etmeyen bir ülke diğer devletleri aldatıp haksız bir avantaj elde etmiş olur ve bu avantajını ilerde diğer ülkelerin güvenliğini ve hatta varlığını tehdit edecek şekilde kullanabilir. Yeni-liberaller, bu durumun tamamen bertaraf edilemese bile azaltılmasında rejimlerin çok önemli rol oynayabileceğini savunurlar. Beklentileri, rejimlerin bunu aktörlerin tercihlerine ait bilgiyi şeffaf hale getirerek, daha da önemlisi izleme ve denetim mekanizmaları yoluyla başarmasıdır. Yani bir rejim tarafından ortaya konan norm ve prensiplere tüm tarafların bağlı kalması yine rejimin kendi iç denetim mekanizması sayesinde mümkün olacaktır. Denetim sonucunda rejim norm ve kurallarını hiçbir haklı gerekçeye dayanmaksızın ve yaygın şekilde ihlâl ettiği saptanan devletlerin bilgisi uluslararası toplum ve kamuoyu ile paylaşılacağı için devletlerin ihlâl konusunda daha dikkatli davranacağı varsayılır. ${ }^{26}$

Bu noktada akla gelen soru, ortak faydadan ziyade bireysel kazancını önemseyen ve önceleyen devletin, ihlâlinin ortaya çıkarılmasından rahatsız olup olmayacağı ve dolayısıyla rejimi ciddiye alıp almayacağıdır. Yeni-liberallere göre söz konusu devlet rejimin, şayet varsa, yaptırım mekanizmaları ve ikinci olarak -belki de daha önemlisi- "şöhret faktörü" nedenlerinden ötürü rahatsız olup, bir daha ihlâlde bulunmamaya gayret gösterecektir. İhlâl karşısında uygulanan yaptırımlar caydırıcılık derecelerine bağlı olarak söz konusu devlet üzerinde etkili olabilir. Fakat genel olarak rejimler etkin yaptırım mekanizmalarından yoksundurlar. ${ }^{27} \mathrm{Bu}$ nedenle yeni-liberallerin asıl üstünde durdukları, rejimlerin

23 Booth ve Wheeler, The Security Dilemma, s.84-87; Keohane, After Hegemony, chap.5.

24 Örneğin bkz., Stein, “Coordination and Collaboration”, s.307-308, 312-313.

25 Ibid.

26 Hasenclever vd., Theories, s.33-35.

27 Robert Axelrod ve Robert O. Keohane, "Achieving Cooperation under Anarchy: Strategies and Institutions”, World Politics, Cilt 38, No.1, 1985, s.250. 
şöhret faktörüne olan etkisi yoluyla işbirliğini mümkün ve sürekli kılmalarıdır. Şöhret faktörü, bir devletin uluslararası toplumda güvenilir ve dolayısıyla kendisiyle işbirliği yapılabilecek bir aktör olup olmamasıyla ilintilidir. Sürekli olarak bağlı olduğu rejim/lerin normlarına aykırı hareket edip, kurallarını ihlâl eden bir devletin uluslararası topluma göndermiş olduğu sinyal güvensizliktir. Böyle bir devlet sadece bağlı olduğu rejimin yaptırımlarına maruz kalmaz, aynı zamanda gelecek işbirliklerinden de mahrum kalma olasılığı ile karşı karşıya kalır. Uluslararası alandaki diğer olası kârlı ortaklıklardan dışlanma ve belki de uluslararası toplumdan tecrit edilme yüzünden doğacak zarar, bu devletin ihlâlde bulunarak sağlamaya çalıştığı haksız avantajı önemsiz kılıp, onu rejim kurallarına uygun şekilde ve dolayısıyla uzun dönemli çıkarlarını göz önüne alarak davranmaya sevk edecektir. ${ }^{28}$

\section{Güç-Bazlı Yaklaşım}

Güç, gerçekçi kuramın temel varsayımlarından bazılarını paylaşan yeni-liberallerin göz ardı ettikleri veya yadsıdıkları bir konu değildir. Kimi yeni-liberal kuramcılar gerçekçi bir kuram olan hegemonik/ başat güç istikrar kuramından yola çıarak, devlet çıkarlarının belirlenmesi ve şekillenmesinde uluslararası güç dağılımının sistem düzeyinde belirleyici olduğunu ve rejimlerin kurulmasında başat güç/ lerin öncü rol oynadığını (ve hatta oynaması gerektiğini) ifade etmişlerdir. ${ }^{29}$ Benzer şekilde, güçlü devletleri barındıran rejimlerin daha etkili (norm ve kurallara uygun davranma anlaminda) ve daha uzun ömürlü olduğu da dile getirilmiştir. ${ }^{30}$ Fakat diğer taraftan neo-liberaller, rejimlerin devamlılığının her zaman sistemik güç dağılımı ile açıklanamayacağını, bir rejime yol açan çıkarlar demetinin güç dağılımındaki değişikliklerden her zaman bire bir etkilenmeyeceğini ve rejim devamlılığını en az güç kadar ve hatta ondan daha fazla sağlayan başka faktörlerin de olduğunu (bilgi, teknoloji ve meşruiyet gibi) savunmuşlardır. ${ }^{31}$

Güç konusunu merkeze alarak rejim konusunu inceleyen ve bu sebeple tüm kuramlar içerisinde bu konuya en temkinli ve hatta en eleştirel bakan yaklaşım gerçekçiliktir. "Anarşik uluslararası sistemde kurala dayalı devletler arası işbirliği mümkün müdür?” sorusuna en çekimser veya kötümser yanıtlar gerçekçilerden gelmiş, yeni-liberallerin uluslararası işbirliği ve dolayısıyla rejim konusundaki öngörüleri farklı noktalarda eleştiriye tabi tutulmuştur. Eleştirilen unsura bağlı olarak ya uluslararası rejimlerin fonksiyonu ve önemi farklı tanımlanmış ya da rejimlerin neden baştan itibaren başarısızlığa uğramaya mahkûm yapılar olduğu ortaya konmaya çalışılmıştır. Bu noktada iki temel yaklaşımı ayırt etmek mümkündür. Bunlardan ilki, uluslararası sistemin anarşik yapısını ve göreceli kazanç konusunu merkeze alıp, bunun neden devletler arası işbirliklerini zora soktuğunu açıklayan yaklaşımdır. Diğeri

28 Keohane, After Hegemony, s.103-106; Hasenclever et.al., Theories, s.34-36.

29 Keohane, After Hegemony, s.100, 135-150. Özünde gerçekçi olan bu görüş uluslararası ekonomi-politik kuramın gerçekçi akademisyenlerinden Robert Gilpin tarafından kuvvetli bir şekilde ortaya konmuştur. Gilpin, uluslararası liberal ekonomik düzen için gerekli olan rejimlerin (ticaret, finans ve diğer alanlarda) etkili ve sağlıklı bir şekilde işleyebilmesi için bu düzenin prensiplerine bağlı ve böyle bir düzeni kendi çıkarlarına uygun gören hegemon bir gücün varlığının gerekli olduğundan bahseder. Gilpin’e göre, hegemon, düzen kurucu, koruyucu ve uluslararası işbirliğini kolaylaştırıcı rollerini baskı ve zorlama yoluyla değil, kendisiyle aynı prensiplere inanan devletlere farklı şekillerde hizmet vererek ve bu devletlerin karşılamaya yanaşmadıkları kolektif varlıkları tek başına karşılayarak icra eder. Düzenin devamı için gerekli olan unsurlar, hegemonun liderlik rolü ve bu rolün gerektirdiği sorumlulukların yerine getirilmesidir. Rejimlerin kurallarına uyulmadığı takdirde uygulanacak yaptırımlar hegemonun ilk değil, en son tercihi olmalıdır. Bkz., Robert Gilpin, Global Political Economy: Understanding the International Economic Order, Princeton, Princeton University Press, 2001, s.95, 97-102.

30 Richard Little, "International Regimes”, John Baylis ve Steve Smith (der.), The Globalization of World Politics: An Introduction to International Relations, Oxford, Oxford University Press, 2001, s.308.

31 Hasenclever vd., Theories, s. 86-87. Ayrica bkz., Joanna Depledge, "Against the Grain: the United States and the Global Climate Change Regime”, Global Change, Peace and Security, Cilt 17, No.1, 2005, s.21-27. 
ise, Krasner'ın da aralarında bulunduğu kimi gerçekçi kuramcıların rejimlerin kurulmasını, devamını ve etkinliğini "koordinasyon" sorunundan yola çıkarak açıklayan yaklaşımdır.

İlk eleştirel yaklaşıma, gerçekçi kuramcılardan Joseph M. Grieco’nun yeni-liberal kurumsalcıllğın uluslararası kurumlara ilişkin argümanlarını ele alıp, bunların yerine gerçekçi önermeler sunduğu çalışması örnek olarak gösterilebilir. ${ }^{32}$ Grieco, yeni-liberallerin genelde devletler arası işbirliği ve özelde de uluslararası kurumlar hakkındaki varsayımlarının uluslararası gerçeği doğru ve tam olarak yansıtmadığını, çünkü bu varsayımların çıkış noktalarının yanlış veya eksik olduğunu iddia etmiştir. Bu çıkış noktalarından ilki, uluslararası sistemin anarşik yapısının anlamı ve olası etkisine, diğeri ise devletlerin doğası ve davranış mantığına ilişkindir. Grieco’ya göre, yeni-liberaller anarşik yapıyı salt kural koyan ve uygulayan merkezi bir otorite yokluğu şeklinde yorumlayarak, devletlerin en önemli kaygısını bu otorite boşluğundan doğabilecek ve verilen sözlerin tutulmaması ya da imzalanan antlaşmaların ihlâli ile tanımlanabilecek aldatılma korkusuna indirgemişlerdir. Dolayısıyla, denetleme ve yaptırım mekanizmalarına sahip uluslararası kurumların bu korkuyu gidererek ve şöhret faktörünü olumlu yönde etkileyerek devletler arası işbirliğini mümkün kılacağını varsaymışlardır. Fakat Grieco’ya göre, bu bir yanılsamadır, çünkü anarşik yapının devlette yol açtığı en temel korku güvenliğine ve varlığının devamına ilişkin olanıdır. Devletlerin niyetlerine ilişkin belirsizlik, yeni-liberallerin iddia ettiğinin aksine kurumlar yoluyla giderilebilecek bir durumdan ziyade, varoluşsal kalıcı bir hal olup, anarşik yapıyla birleşince devletler arası şüphecilik ve güvensizlik hali sürekli olarak kendini yenilemektedir. ${ }^{33}$

Başlıca çıkarları ekonomik refahtan ziyade varlıklarını sürdürmek olan devletler kendi başlarının çaresine bakmak ve bunun için de gerekli güç donanımına sahip olmak zorundadırlar. ${ }^{34}$ Grieco, böyle bir zorunlulukla karşı karşıya kalan devletin temel hedefinin bireysel kazancını maksimize etmekten ziyade, diğer devletlerin kendisine karşı göreceli kazanç elde etmesini engellemek olduğunu savunur. Devletler, yeni-liberallerin iddia ettiği gibi çıkar ve kazançlarını başkalarınınkinden bağımsız hesaplayan egoistler değil, göreceli pozisyonlarını kollamaya ve korumaya çalışan aktörlerdir. Söz konusu pozisyonel duruma gösterilen duyarlılık devleti işbirliği yapmaktan alıkoyabilir, çünkü işbirliği diğer ortaklara daha fazla kazanç sağlayıp devletin göreceli pozisyonunu olumsuz yönde etkileyebilir. Yani işbirliği sonunda tüm devletler işbirliği öncesi durumlarına göre mutlak anlamda daha kazançlı bir konuma gelseler de, ortaklarının kendilerine karşı göreceli kazanç elde edecek olması veya böyle bir ihtimalin varlığı göreceli kayıpla karşı karşıya kalan devletleri işbirliği yapmaktan vazgeçirecektir. ${ }^{35}$

Grieco göreceli kazanç konusunun işbirliğinin önünde aşılması zor bir engel olmasının uluslararası ilişkilerde niyetlere ilişkin varoluşsal ve giderilemeyen bir belirsizlikten kaynaklandığını, bugünün dostunun yarının düşmanı olabileceğini ve bu durumun da devlet adamını en kötü olasılıkları hesaba katarak hareket etmeye zorladığını savunur. Bununla beraber göreceli kazanç duyarlılığı, Grieco'ya göre, her durumda aynı değildir. Özellikle işbirliği yapılacak ortak, devletin uzun dönemli bir rakibi ise, işbirliği alanı ekonomik refahtan ziyade güvenlikle ilgiliyse, devletin göreceli gücü hâlihazırda düşüşteyse, işbirliğinden elde edilecek kazanç kolaylıkla bir güç kabiliyetine dönüştürülmeye elverişli ise ve şayet bu elde edilecek güç ve nüfuz diğer alanlarda da kullanılabilecekse, Grieco göreceli kazanç duyarlılığının yüksek ve dolayısıyla işbirliği isteğinin de az olduğunu iddia etmiştir. Fakat son tahlilde uluslararası ilişkilerin belirsizlikleri göz önüne alındığında müttefiklerle olan ortaklıklarda bile bu

32 Joseph M. Grieco, "Anarchy and the Limits of Cooperation: A Realist Critique of the Newest Liberal Institutionalism", International Organization, Cilt 42, No.3, 1988, s.485-507.

33 Ibid., s.497-498.

34 Ibid., s.498.

35 Ibid., s.498-500. 
duyarlılı̆̆ın sıfırdan fazla olacağı söylenmiştir. Bu şartlar altında en olası işbirliği, kazançların ortaklar arasında dengeli ve eşit dağıtıldığı, yani işbirliği öncesi ve sonrası göreceli güç pozisyonlarının muhafaza edildiği ortaklık çeşididir. ${ }^{36}$

Grieco'nun yanı sıra John Mearsheimer ve Kenneth Waltz gibi kimi gerçekçiler bahsedilen nedenlerden ötürü uluslararası işbirliği veya rejimlere fazla bir şans tanımazken, ${ }^{37}$ Stephen Krasner gibi diğerleri hâlihazırda kurulmuş rejimleri açıklamak üzere yeni-liberaller gibi oyun kuramlarından yararlanmışlardır. ${ }^{38} \mathrm{Bu}$ ikinci gruba göre, uluslararası arenada devletlerin karşı karşıya kaldıkları işbirliği ve çatışma halini daha çok resmeden oyun modeli, "mahkûm ikilemi”nden ziyade, özünde bir koordinasyon sorunu barındıran "cinsiyetler savaşı"dır. Söz konusu koordinasyon sorunu, eş değerde optimal tercihlere sahip devletlerin bağımsız hareket etmeleri halinde karşılıklı olarak olmamasını arzu ettikleri veya en az istedikleri durumla karşı karşıya kalma sorunudur. Burada "mahkûm ikilemi”nden farklı olarak niyetlerin belirsizliği ve buna bağlı güvensizliğin yol açtığı bir işbirliği sorunu değil, koordinasyon eksikliği sonucu ortaya çıkan bir durum mevcuttur. Aktörlerden herhangi birinin isteği doğrultusunda ortak hareket edildiğinde, yani koordinasyon sonucu mevcut isteklerden biri seçildiğinde, en az arzu edilen veya hiç arzu edilmeyen sonuç önlenmiş olacaktır. Trafiğin sağdan ya da soldan akması buna en tipik örnek olarak gösterilirken, uluslararası alanda da koordinasyon sorunlarının (ve çözümlerinin) pek çok örneği vardır: Örneğin hava kontrol kulelerinin uluslararası dil olarak İngilizce’yi benimsemeleri ve radyo frekanslarının ülkeler arasındaki paylaşımı gibi. ${ }^{39}$

Yeni-liberaller ciddi paylaşımsal sorular içermeyen minimal koordinasyon sorunlarının aşılmasında ve söz konusu uzlaşı noktasının kurumsallaşmasında rejimlerin önemli bir rol oynadığını savunmuşlardır. Örneğin, Arthur Stein gücü merkeze alan bir analiz yapmamış, bağlam (context), teknoloji ve meşruiyet gibi faktörlerin (güce ilaveten veya güçten bağımsız olarak) ortak tercihin belirlenmesinde önemli rol oynadığını belirtmiştir. ${ }^{40}$ Buna karşılık, gerçekçi kuramcılardan Krasner, koordinasyon sorunlarında en sık rastlanan durumun aktörlerin optimal tercihleri arasında seçim yaparken yaşandığını ve çoğunlukla bu seçimde güç dağılımının ve dolayısıyla göreceli güç kabiliyetlerinin önemli rol oynadığını vurgulamıştır. Buna göre, işbirliğine kimlerin dâhil edileceği, varılacak anlaşmanın içeriği ve bunun nasıl belirleneceğine dair konularda devletin gücü asıl belirleyici konumdadır. İkinci Dünya Savaşı sonrası kurulan ticaret ve finans rejimlerinin yanı sıra, uluslararası elektromanyetik dalga ve telekomünikasyon rejimleri, ilgili koordinasyon sorunlarını güç temelinde çözüme kavuşturan rejim örnekleri arasında gösterilmiştir. Bu rejimlerin koordinasyon noktalarının, yani norm ve prensiplerinin belirlenmesinde güçlü aktörlerin tercihleri belirleyici olmuştur. ${ }^{41}$

Koordinasyon sorununu aşmak için kurulacak rejimin işlevi, “mahkûm ikilemi”ndekine benzer çıkar-bazlı bir sorunu çözmek için oluşturulan rejimden farklı olacaktır. Şöyle ki, koordinasyon rejimi bir kez kurulduktan sonra, yani aktörlerden birinin tercihi doğrultusunda seçim yapılıp gerekli antlaşmalar imzalandıktan sonra, bu rejim çoğu zaman herhangi bir iç denetim ve yaptırım mekanizmasına gerek duyulmadan işlemeye devam edecektir. Burada herhangi bir aldatma korkusu veya şöhret faktörü söz konusu değildir; çünkü aktörlerin rejim kurallarına aykırı hareket etmeleri kendilerine bireysel

36 Ibid., s.500-502.

37 John J. Mearsheimer, “The False Promise of International Institutions”; Kenneth N. Waltz, Theory of International Politics, s.104-107.

38 Stephen D. Krasner, "Global Communications and National Power: Life on the Pareto Frontier”, World Politics, Cilt 43, No.3, 1991.

39 Stein, "Coordination and Collaboration", s.309, 314-315.

40 Ibid., s.311.

41 Krasner, "Global Communications and National Power", s.336-366. 
kazanç değil, kayıp şeklinde geri dönecektir. Şayet aktör bu şekilde hareket ediyorsa, bu onun haksız kazanç elde etmek istemesinden değil, rejimin norm ve kurallarından duyduğu hoşnutsuzluğu dile getirmek ve ortaklarını farklı bir çözüme zorlamak içindir. ${ }^{42}$ Nitekim yukarıda adı geçen koordinasyon amaçlı rejimlere (uluslararası elektromanyetik dalga ve telekomünikasyon rejimleri) katılan az gelişmiş ve gelişmekte olan ülkeler, bu rejimlerin ilgili örgüt yapılarında toplu halde hareket ederek, yani güç birliği yaparak rejimlerin kimi norm, kural ve karar alma mekanizmalarında kendi tercihleri doğrultusunda birtakım değişiklikler yapılmasını başarmışlardır. ${ }^{43}$

Diğer taraftan, dünya ticaret rejimindeki az gelişmiş ve gelişmekte olan ülkeler sayısal üstünlüklerini aralarında güç birliği yaparak çoğu kez bir avantaja dönüştüremediklerinden, kendi ticari çıkarlarıyla çelişen ekonomik antlaşmaların gelişmiş ülkelerin girişimleriyle Dünya Ticaret Örgütü’nde (DTÖ) kabul edilmesine engel olamamışlardır. Söz konusu koordinasyon eksikliğinin sebepleri çeşitli olmakla beraber, en önemlileri "güç" faktörünün belirleyiciliğini ortaya koymaktadır. Örneğin, görünüşteki demokratik yapısına rağmen DTÖ’nün gelişmiş ülkelerin kendi aralarında oluşturdukları ve gelişmekte olan ülkeler üzerinde baskı ve tehdit unsuru olarak kullandıkları gayrı resmî karar alma mekanizmaları, gelişmekte olan ülkelerin DTÖ bünyesinde yeterli teknik donanıma ve müzakere kapasitesine sahip olmayışları ve bu ülkelerin maliyet sebebiyle DTÖ bünyesinde gelişmiş ülkeler kadar yeterli personel bulunduramayışları güç faktörüyle ilişkilendirilmiştir. ${ }^{44}$ Son tahlilde, gerçekçi yaklaşıma göre devlet gücü, ister bir hegemon güç tarafından, isterse toplu halde kullanılsın, rejimlerin kurulması ve değişime uğramasında yeni-liberallerin varsaydığından çok daha belirleyici bir rol oynamıştır ve oynamaya devam etmektedir.

\section{Bilgi-Bazlı Yaklaşım}

Krasner'in yukarıda belirtilen klasik rejim tanımındaki “aktörlerin örtüşen beklentileri” ifadesi, karar alıcıların öznesel/sübjektif ve bilişsel dünyasına dikkat çekmektedir. Benzer şekilde rejimleri, aktörlerin meşru veya doğru davranışa ilişkin örtüşen anlayış, beklenti veya inançları şeklinde tanımlayanlar vardır. ${ }^{45}$ Kratochwil ve Ruggie bir adım daha ileri giderek rejimlerin özneler-arası (intersubjective) bir ontolojiye sahip olduğunu iddia etmiştir. ${ }^{46} \mathrm{Bu}$ tanımlarda öznesel yapıya yapılan vurgu, insan akılcılığının aslında sınırlı ve çevresinden gelen bilgiye karşı seçici olduğunu ortaya koymaktadır. ${ }^{47}$

Uluslararası rejimlerin kurulmasının ve sonrasında geçirdiği değişikliklerin açıklanmasında salt çıkar ve/veya güç bazlı varsayımlara dayanmanın yanlış olmasa bile eksik olduğu görüşü, fikir (idea) ve bilginin (knowledge) uluslararası ilişkilerde oynadığı rolü inceleyen bilişsel yaklaşımların giderek daha fazla rejim kuramına ilgi göstermesine yol açmıştır. Her ne kadar kendi içlerinde özellikle epistemolojik yönden farklı eğilimleri barındırsalar da, bilişsel yaklaşımların temel çıkış noktası bilginin, ister nedensel ister normatif temelli olsun, uluslararası ilişkiler aktörlerinin kimlik ve/veya çıarlarının

42 Stein, "Coordination and Collaboration", s. 313-314.

43 Krasner, "Global Communications and National Power”, s.351-353.

44 Söz konusu sebeplerin daha ayrıntılı analizi için bkz., S. Javed Maswood, The South in International Economic Regimes: Whose Globalization?, New York, Palgrave Macmillan, 2006, s.161-182.

45 Örneğin bkz., Young, "International Regimes”, s.107; Donald J. Puchala ve Raymond F. Hopkins, "International Regimes: Lessons from Inductive Analysis”, International Organization, Cilt 36, No.2, 1982, s.246; Andreas Hasenclever, Peter Mayer ve Volker Rittberger, "Integrating Theories of International Regimes”, Review of International Studies, Cilt 26, No 1, 2000, s.3.

46 Kratochwil ve Ruggie, "International Organization”, s.764.

47 Christer Jönsson, “Cognitive Factors in Explaining Regime Dynamics”, Rittberger (der.), Regime Theory, s.203. 
tanımlanması ve süregiden inşasında çok önemli bir rol oynadığıdır. Bu yaklaşımlar, çıkar-bazlı ve güçbazlı kuramların söz konusu inşa süreçlerini görmezden gelerek, kimlik ve çıkarların değişime açık ve dinamik olgular olduğunu yadsıdığını ve bu yadsımanın da aktör davranışı açıklamalarını yanlış veya eksik kıldığını savunurlar. ${ }^{48}$

Literatürde bilgi-bazlı yaklaşımlar zayıf ve kuvvetli olmak üzere iki gruba ayrılmıştır. Burada söz konusu ayrım, bilişselcilerin gerçekçi ve yeni-liberal kuramların rasyonel varsayımlarına ne derece eleştirel yaklaştıklarıyla ilgilidir. ${ }^{49}$ Zayıf bilişselciler diye bilinenler, bu varsayımları ve özellikle de bu varsayımların temelinde yer alan "bireysel çıkarını maksimize etmeye çalışan rasyonel aktör” tanımını eleştirmek yerine, bilgi ve fikirlerin devletlerin çıkar ve tercih oluşumu ile strateji seçiminde oynadığı rolü ortaya koyarak, tamamlayıcı bir katkı sunmaya çalışırlar. ${ }^{50}$ Bilişselcilere göre bilgi ve fikirler bir rejimin kuruluşundan başlayarak onun devamı, dönüşümü veya sona ermesinde belirleyicidirler. Bir rejimin kurulmasına yol açan konunun "sorun" olarak tanımlanabilmesi için, her şeyden önce aktörlerin karşı karşıya kaldıkları "gerçekliği” benzer şekilde yorumlayarak bu sonuca varmaları gereklidir. ${ }^{51}$ Yorumlama sürecinde aktörlerin sahip oldukları nedensel veya normatif inançların işlevsel olduğu ve bu inançların da güç dağılımı ve refah gibi maddi faktörlerden kısmen bağımsız oldukları varsayılır. Dolayısıyla aktörlerin çıkar ve tercihlerinin oluşmasında veya değişmesinde bilişsel faktörlerin (kısmen) bağımsız birer değişken olarak incelenmesi gerektiği savunulmuştur. ${ }^{52}$

Zayıf bilişselciler, devletlerin birbirine olan bağımlılı̆̆ının arttığı ve uluslararası konuların giderek teknik bir yapıya büründügü uluslararası ortamda karar alıcıların eskisinden daha fazla bilimsel ve güvenilir bilgiye muhtaç hale geldiğini, ancak bu bilginin yardımıyla çıkarlarını daha sağlıklı tanımlayıp harekete geçebileceklerini savunurlar. Bu bağlamda özellikle teknik bilgi üreten ve yayan bilim uzmanları söz konusu belirsizliğin azaltılmasında veya giderilmesinde işlevsel bir rol oynarlar. Yeniliberallerin rejimlerle üstesinden gelmeye çalıştıkları belirsizlik, devletlerin verdikleri sözlere veya imzaladıkları antlaşmalara bağlı kalıp kalmayacaklarıyla ilişkin niyet belirsizliği iken, zayıf bilişselciler karar alıcıların hedef ve strateji belirleme aşamasında karşılaştıkları belirsizlikle ilgilenirler. Özellikle teknik konulara ilişkin alanlarda amaçlar ve araçlar belirlenirken, devlet yetkililerinin kendilerine sunulan bilimsel veya diğer güvenilir verileri kullanarak belirsizlik azaltıcı bir rol oynadıkları, hedef ve politikalarını bu verilere dayanarak belirledikleri ve bu tip verileri yayan rejimlerin bu yönde dolaylı da olsa önemli bir katkı sundukları ifade edilmiştir. ${ }^{53}$

48 Hasenclever vd., Theories, s.136.

49 Andreas Hasenclever, Peter Mayer ve Volker Rittberger, "Interests, Power, Knowledge: The Study of International Regimes”, Mershon International Studies Review, Cilt 40, No.2, 1996, s.206.

50 Örneğin, Judith Goldstein ve Robert Keohane’nin derleme kitabında yer alan çalışmaların önemli bir kısmı, akılcı yaklaşımı koruyarak, "dünya görüşleri”, "normatif inançlar” ve "nedensel inançlar” kategorileri altında farklı fikir tiplerinin dış politikaya etkilerini incelemektedir. Zayıf bilişselcilere güzel bir örnek oluşturan bu çalışmalar için bkz., Judith Goldstein ve Robert O. Keohane (der.), Ideas and Foreign Policy: Beliefs, Institutions, and Political Change, Ithaca, Cornell University Press, 1993.

51 Hasenclever vd., "Interests, Power, Knowledge", s.206.

52 Hasenclever vd., Theories, s.137; Judith Goldstein ve Robert O. Keohane, "Ideas and Foreign Policy: An Analytical Framework", Goldstein ve Keohane (der.), Ideas and Foreign Policy, s.3-30.

53 Hasenclever vd., Theories, s.140-141. Farklı konu alanlarında bilgi topluluklarının (epistemic communities) sunduğu önemli katkılara örnek olarak bkz., Raymond F. Hopkins, "Reform in the International Food Aid Regime: The Role of Consensual Knowledge”, International Organization, Cilt 46, No.1, 1992, s.225-264; Emanuel Adler, "The Emergence of Cooperation: National Epistemic Communities and the International Evolution of the Idea of Nuclear Arms Control”, International Organization, Cilt 46, No.1, 1992, s.101-145; Peter M. Haas, "Banning Chlorofluorocarbons: Epistemic Community Efforts to Protect Stratospheric Zone”, International Organization, Cilt 46, No.1, 1992, s.187-224. 
Karar alıcıları etkileyen ve söz konusu belirsizlikleri azaltan veya gideren fikirler nedensel ve normatif olarak iki grupta toplanmıştır. Nedensel fikirler, sebep-sonuç ilişkisini irdeleyen ve bu yönüyle karar alıcılara siyasi öncelik ve strateji belirlemede yardımcı olan fikirlerdir. Örneğin, küresel ısınmanın doğal olarak değil, insan kaynaklı emisyonlardan kaynakladığını ortaya koyan nedensel bilimsel veriler, çevre rejimlerinin kurulmasına, karar alıcıların başta sanayileşme ve enerji olmak üzere ilgili devlet politikaları üzerinde yeniden düşünmelerine ve harekete geçmelerine yol açmıştır. ${ }^{54}$ Normatif fikirler ise doğru-yanlış, meşru-gayrimeşru veya haklı-haksız ayrımlarından yola çıkarak karar alıcılara ilkesel olarak yol göstermede ve hedef belirlemede yardımcı olurlar. ${ }^{55}$ Hâlihazırda faaliyet gösteren çeşitli rejimler, normatif fikirlerin ya bir hegemon gücün onları sahiplenmesiyle (köleliğin İngiltere öncülügünde yasaklanması gibi) ya da uluslararası toplumda özneler-arası bir nitelik kazanmasıyla (insan hakları rejimleri, kara mayınlarını, kimyasal ve biyolojik silahları yasaklayan rejimler gibi) kurulmuştur. Zayıf bilişselciler, gerek nedensel gerekse normatif fikirlerin bir rejim bünyesinde kurumsallaştıktan sonra, herhangi yeni bir bilimsel buluş veya normatif değişim sonucu dönüşüme uğramadığı sürece, devlet politikalarını sınırlandıracağını savunurlar. ${ }^{56}$

Kratochwil ve Ruggie’nin vurguladığı rejimin özneler-arası yapısı, rejimlerin “üzerinde uzlaşı sağlanan bilgi” (consensual knowledge) ile kurulduğunu ima eder. Bir rejim ilk aşamada böyle bir uzlaşı ile değil de hegemon güç/ler önderliğinde kurulmuş olsa bile, hegemonun kurmuş olduğu uluslararası düzen ve bu düzenin parçası olan rejimler sadece güç kullanımı veya bunun tehdidi ile ayakta kalamazlar; çok daha önemli olarak bu düzenin uluslararası toplumun çoğunluğu tarafından meşru olarak görülmesi lazımdır. ${ }^{57} \mathrm{Bu}$ bağlamda bilişselciler özellikle teknik konulara ilişkin rejimlerin kurulmasında, bilgi toplulukları (epistemic communities) olarak adlandırılan belli bir alan üzerinde uzmanlaşmış profesyonellere büyük önem atfederler. Çoğunlukla bilim adamlarından oluşan bilgi toplulukları, herhangi bir ulus aşırı konunun "sorun" olarak devletlerin gündemine sokulmasında ve tanımlanmasında, rejim kurulması dâhil olacak şekilde çözüm önerileri sunulmasında, farklı devlet politikalarının eş güdümlü hale getirilmesinde ve bir rejim oluşturulmuşsa, devletlerin politikalarının söz konusu rejimin norm ve kuralları ile uyumlu hale getirilmesinde önemli bir rol oynarlar. ${ }^{58}$ Burada varsayılan, bilgi topluluğunun kendi içerisinde uzlaşı sağlamış olması ve bu topluluğun ürettiği bilginin de devletleri ilgili konu hakkında işbirliğine teşvik etmek veya zorlamak için kullanılmasıdır. Aynı konu üzerinde birbiriyle rekabet halinde farklı bilgileri geliştiren ve yayan bilgi topluluklarına maruz kalan devletlerin son kararlarının bilgi temelli yerine siyasi olması muhtemeldir. Böyle durumlarda, karar alıcıların neden bir bilgi topluluğunu diğer/lerine tercih ettiği ve bu tercihte sunulan bilginin bilimselliğinden ziyade, başka faktörlerin rol oynayıp oynamadığı araştırılması gereken konulardır. ${ }^{59}$

Rejim kuramı içinde kuvvetli bilişselciler diye bilinenler, özellikle İngiliz Okulu veya sosyal inşacı kuram geleneğinden gelen veya bunların varsayımlarından yola çıkanlardır. Uluslararası siyaset, uluslararası hukuk, felsefe ve siyasi ekonomi gibi Uİ disiplininin farklı alt dallarında konumlanan teorisyenler içinde, ortak paydaları maddi kuramların rasyonel varsayımlarını yeniden

54 Örneğin bkz., Lindsay Emma Johnson, Advocates, Experts or Collaborative Epistemic Communities? Defining the Scientific Role of NGOs in International Environmental Negotiations, Yayınlanmamış yüksek lisans tezi, Canada, the University of British Columbia, 2006. https://circle.ubc.ca/bitstream/handle/2429/17646/ubc_2006-0210.pdf? sequence $=1$ (Erişim Tarihi 4 Aralık 2014).

55 Hasenclever vd., Theories, s.143-144.

56 Ibid., s.144; Goldstein ve Keohane, "Ideas and Foreign Policy: An Analytical Framework", s.12-13.

57 Hasenclever vd., Theories, s.90-92.

58 Hasenclever vd., "Interests, Power, Knowledge”, s.209-210. Ayrıca bkz. dipnot 53.

59 Hasenclever vd., Theories, s.150, 153. 
inceleyerek eleştirmek ve onlar yerine alternatifler geliştirmek olan düşünürler (Alexander Wendt, Friedrich Kratochwil, Jurgen Habermas ve Robert Cox gibi) bulunmaktadır. Bu düşünürlerin rejim kuramına ilişkin argümanlarının sistematik ve düzenli olmamasına rağmen, farklı ontolojik ve epistemolojik duruşları onlara disiplinde önemli ve ayrıcalıklı bir yer kazandırmıştır. Genelde uluslararası ilişkilerin ve özelde de devlet dâhil tüm aktörlerin sosyalliklerine yapılan vurgu, ontolojik olarak bu grubu akılcı ve maddi kuramlardan ayıran en belirgin özelliktir. ${ }^{60}$ Maddenin ona yüklenen sosyal anlamla değer ve önem kazandığı, aktörlerin kimlik ve çıkarlarının sosyal iletişimden bağımsız ve güç dağılımı gibi salt maddi faktörlerle açıklanamayacağı ile uluslararası normatif yapıların aktörlerin davranışını doğrudan etkilediği argümanları bu bağlamda dikkat çekicidir. ${ }^{61}$ Sosyalliğe yapılan vurgu epistemolojik olarak yorumsamacı yöntemi ön plana çıkarmaktadır. Bu grup içerisinde Wendt gibi pozitivist epistemolojiyle bağlarını tamamen koparmamış düşünürler bulunsa da, asıl hedefi sosyal boyutu sadece açıklamak değil, aynı zamanda anlamak olanlar yorumsamacı yöntemlere yönelmişlerdir. ${ }^{62}$

Hasenclever, Mayer ve Rittberger, kuvvetli bilişselcilerin rejim kuramıyla ilgili argümanlarını birbiriyle yakından ilişkili üç alt başlık altında toplamışlardır: meşruiyetin gücü, argümanın gücü ve kimliğin gücü. ${ }^{63}$ Her bir başlıktaki argümanların temelini, karar alıcıların akılcı kuramlarda varsayılan araçsal/sonuçsal mantık (instrumental logic veya the logic of consequences) yerine uygunluk mantığı (the logic of appropriateness) ile hareket ettikleri varsayımı oluşturur. ${ }^{64}$ Buna göre, herhangi bir konuda politika ve stratejiler belirlenirken bunların önceden belirlenmiş genellikle maddi hedefleri ne kadar gerçekleştireceği düşüncesinden ziyade, ait olunan topluluğun norm, kural ve değerlerine uygun olup olmadığı dikkate alınır. Bu bağlamda devletler, çıkarlarını maksimize etmeye çalışan aktörler değil, uluslararası toplum bilinci ve sorumluluğu ile rollerini oynayan aktörlerdir. Uluslararası toplumun norm, kural ve değerleri, devletlerin ve bu toplumun diğer aktörleri üstünde belirleyici, yönlendirici ve/veya sinırlandırıcı etkiye sahiptir. ${ }^{65}$

"Meşruiyetin gücü” argümanı, rejimlerin gücünün (hem sürdürülebilir dayanıklılık hem de etkililik anlamında) uluslararası toplumun normatif yapılarına gömülü olmalarından ileri geldiğini savunur. Yani, devletlerin üyesi bulundukları rejimlerin norm ve kurallarına uygun hareket etmele-

60 Ibid., s. 155 .

61 Sosyal inşacı varsayımları ve bu varsayımları içeren çalışmaları gözden geçiren literatür çok zengindir. Örnek olarak bkz., K. M. Fierke, “Constructivism”, Tim Dunne, Milja Kurki ve Steve Smith (der.), International Relations Theories: Discipline and Diversity, Oxford, Oxford University Press, 2007, s.168-184; Martha Finnemore ve Kathryn Sikkink, "Taking Stock: The Constructivist Research Program in International Relations and Comparative Politics", Annual Review of Political Science, Cilt 4, 2001, s.391-416; Christian Reus-Smit, "Constructivism”, Scott Burchill vd., Theories of International Relations, New York, Palgrave Macmillan, 2005, s.188-212; Maja Zehfuss, Constructivism in International Relations: The Politics of Reality, Cambridge, Cambridge University Press, 2004.

62 Örneğin bkz., Friedrich Kratochwil, “The Protagorean Quest: Community, Justice, and the 'Oughts' and 'Musts' of International Politics", International Journal, Cilt 43, No.2, 1988, s.205-240; Jutta Weldes, "Constructing National Interests”, European Journal of International Relations, Cilt 2, No.3, s.275-318; Jens Bartelson, A Genealogy of Sovereignty, Cambridge, Cambridge University Press, 1995.

63 Bu bağlamda, "meşruiyetin gücü”ne ilişkin olarak İngiliz Okulu ve uluslararası hukuk kuramcılarının (örneğin, Andrew Hurrell, Hedley Bull, Thomas M. Franck, Louis Henkin, vb); “argümanın gücü”ne ilişkin olarak kural-yorumlama ve kural-uygulamanın özneler arası iletişimsel boyutunu çalışan sosyal inşacı kuramcıların (Friedrich Kratochwil, Harald Müller, John G. Ruggie, vb); ve “kimliğin gücü”ne ilişkin olarak da Alexander Wendt'in argümanları incelenmiştir. Bkz., Hasenclever vd., Theories, s.167-192.

64 Söz konusu eylem mantıkları (logics of action) ve aralarındaki ilişki hakkında daha fazla bilgi için bkz., James G. March ve Johan P. Olsen, “The Institutional Dynamics of International Political Orders”, International Organization, Cilt 52, No.4, 1998, s.949-954.

65 Hasenclever vd., Theories, s.155-157. 
ri akılcı kuramların iddia ettiklerinin aksine dışsal teşvik veya yaptırım mekanizmaları yolu ile değil, devletlerin uluslararası toplumun üyeleri oldukları için gerçekleşmektedir. Buna göre rejimlerin devletlerin varlıklarını borçlu oldukları egemenlik, diplomasi ve uluslararası hukuk gibi derin normatif yapılar üstüne inşa edilmeleri ve bu yapıların da karşlıklılık ve pacta sund servanda (ahde vefa) gibi ilkeleri kapsaması nedenleriyle devletler uluslararası toplumun ortak çıkarlarını gerçekleştirmek üzere oluşturdukları bu rejimlerin norm ve kurallarıyla çoğu kez bir sorumluluk bilincinde ve gönüllü olarak uyum içinde hareket ederler. ${ }^{66}$ Aksi bir hareket kısa vadeli yarar sağlasa da, devletin uzun dönemde ç1karlarını tehlikeye atacaktır; zira normatif yapıların zarar görmesi devletin varlığının da zarar görmesi anlamina gelecektir. ${ }^{67}$

Burada doğal olarak akla gelen ilk soru, her rejim norm ve kuralının benzer çekim gücüne sahip olup olmadı̆̆ıdır; yani devletler her birine aynı derecede uyacaklar mıdır? Özellikle uluslararası hukuk geleneğinden gelen düşünürler, meşruiyetini uluslararası toplumun normatif yapıları ile uyum içinde olmasından alan rejimlerin norm ve kurallarının uzun ömürlü ve etkili olacağını savunmuşlardır. Bu bağlamda meşru norm ve kurallar ile işbirliği yapan devletlerin geçici çıkarları üzerine oturan kurallar arasında bir ayrım yapılmış ve ilkinin daha dayanıklı olduğu iddia edilmiştir. ${ }^{68}$ Fakat uluslararası alanda norm ve kural ihlâlinin bunlara uymak kadar bir gerçek olduğu göz önüne alındığında, kuvvetli bilişselcilerin de yeni-liberaller gibi hangi şartlar altında bu uyumun gerçekleştiğini ve özellikle devletlerin sorumluluk bilinci ile hareket ettiğini daha ayrıntılı açıklamak zorunda oldukları ifade edilmiştir. ${ }^{69}$

"Argümanın gücü”, kuvvetli bilişselcilerin rejimlerin kurulma ve bunu izleyen aşamalarda iletişimin oynadığı role ilişkin olarak üzerinde durdukları bir konudur. Kratochwil ve Ruggie, yukarda açıklandığ anlamı, rejimlerin esas olarak çoğu kez aktörler arası görüşme ve müzakereler sonucu üzerinde mutabık kalınan beklentiler ve bunların ifade edildiği yazılı, sözlü veya imâ edilen anlaşmalar üstüne inşa edildiğidir. Yani rejimlerin temelinde uluslararası ilişkilerin herhangi bir sorununa ilişkin olarak doğru ve yerinde davranmanın ne olduğuna dair paylaşılan anlayış ve beklentiler vardır. ${ }^{71}$ Rejimlerin kurulmasında söz konusu mutabakat ve paylaşımın ortaya çıkmasını sağlayan iletişimin, sonraki aşamalarda da önemli roller oynadığı ifade edilmiştir. Kuvvetli bilişselciler, özellikle norm ve/veya kural ihlâli ve rejim etkinliği arasında kurulan ilişkiye farklı bir noktadan bakarlar. Buna göre her ihlâl, gerekçeleriyle beraber değerlendirilmelidir. Bir rejim bünyesinde ihlâlde bulunan üyenin sunduğu özür ve

66 Uluslararası toplum kavramını ortaya koyup bu toplumun tarihsel ve mekânsal olarak geçirmiş ve geçirmekte olduğu dönüşümü inceleyen İngiliz Okulu kuramcıları, uluslararası hukuk, diplomasi ve egemenlik kavramlarını birer kurum olarak ele alırlar. Devletlerin kendi oluşturdukları bu kurumlarla olan ilişkilerini irdeleyen çalışmalara örnek olarak bkz., Robert Jackson, The Global Covenant: Human Conduct in a World of States, Oxford, Oxford University Press, 2003; Alan James, "Law and Order in International Society", Alan James (der.), The Bases of International Order: Essays in Honour of C. A. W. Manning, London, Oxford University Press, 1973, s.60-84; David Armstrong, "The Nature of Law in an Anarchical Society", Richard Little ve John Williams (der.), The Anarchical Society in a Globalized World, New York, Palgrave Macmillan, 2006, s.121-140; Ian Hall, "Diplomacy, Anti-diplomacy and International Society”, Little ve Williams (der.), s.141-161; Peter Wilson, “The English School's Approach to International Law”, Cornelia Navari (der.), Theorising International Society: English School Methods, New York, Palgrave Macmillan, 2009, s.167-188.

67 Hasenclever vd., Theories, s.170-171.

68 Ibid., s.172-173. Bu konuyla ilgili olarak en net ve kuvvetli argümanlar Thomas Franck tarafından ortaya konmuştur. Bkz., Thomas Franck, The Power of Legitimacy Among Nations, Oxford, Oxford University Press, 1990.

69 Hasenclever vd., Theories, s.174-175.

70 Bkz. dipnot 17. Ayrıca bkz., John G. Ruggie, Constructing the World Polity: Essays on International Institutionalization, New York, Routledge, 1998, s.85, 89-91.

71 Hasenclever vd., Theories, s.176. 
sebepler rejimin üstüne oturduğu ortak anlayış ve beklentiler çerçevesinden ele alınarak incelenmelidir. Sunulan inandırıcı gerekçelere bağlı olarak, ihlâl istisnai ve kabul edilebilir bulunabilir veya ihlâl edilen kuralın değiştirilmesi bile gündeme gelebilir. Rejimin varlığını tehlikeye sokan ve yaptırıma tabi tutulması istenen ihlâller, gerekçeleri diğer üyeler tarafından yerinde veya haklı bulunmayan ve/ veya yaygın olan ihlâllerdir. Yani kuvvetli bilişselciler özellikle yeni-liberallerden farklı olarak yaptırım mekanizmasını hemen devreye sokmadan evvel, üyeler arası iletişim yoluyla ihlâli anlamlandırmaya ve değerlendirmeye çalışırlar. ${ }^{72}$

Kuvvetli bilişselciler söz konusu iletişimin sadece ihlâl durumlarında değil, rejimin tüm yaşamı boyunca devam ettiğini ve tarafların sürekli olarak rejimin prensip, norm, kural ve karar alma prosedürlerini değişen şartlara bağlı olarak yorumlamaya tabi tutarak, gerekli düzenlemeleri yaptığını ve yorumlama sürecinde de ikna yönteminin dikkate değer olduğunu vurgularlar. ${ }^{73}$ Yalnız rejim içi tartışmaların sağlıklı yürüyebilmesi ve istenen sonucu verebilmesi için öne sürülen bazı şartlar da vardır: Taraflar birbirini eşit olarak görmeli, zarar vermeme prensibi benimsenmeli ve iyi/haklı sebepler içeren antlaşmaların bağlayıcılığı kabul edilmelidir. Ayrıca, sunulan argümanların kabul görmesi için evrensel prensipler ve ortak anlayışlara dayandırılması lazımdır. Bu tip prensiplere dayanmayan bireysel yorumlar ve uygulamaların, rejim varlığını tehlikeye atacağı için dikkate alınmayacağı veya alınmaması gerektiği savunulmuştur. ${ }^{74}$ Fakat Kratochwil'in dikkat çektiği gibi, pazarlık ve güce dayalı unsurlar uluslararası ilişkilere diyalog ve iknadan daha çok damgasını vurduğu için, son tahlilde, devlet davranışında bu unsurların mı yoksa iletişimin mi etkili olduğunu saptamak zordur ve bu sorun henüz bilimsel anlamda tam olarak çözüme kavuşturulamamıştır. ${ }^{75}$

Son olarak, "kimliğin gücü” argümanı, rejimlerin, devletlerin kimliklerini dönüştürücü etkiye sahip olduğu varsayımına dayanır. Daha önce de bahsedildiği gibi, rejim kuramındaki yeniliberal ve gerçekçi yaklaşımlar, devletlerin çıkar ve kimliklerini ve özellikle nasıl inşa edildiklerini sorgulamazlar. ${ }^{76} \mathrm{Bu}$ yaklaşımlarda çıkar ve kimlikler yapılan işbirliklerinden etkilenmeyen ve değişime uğramayan durağan kavramlar görünümündedir. Yeni-liberal yaklaşım, belirsizliğin hâkim olduğu durumlarda çıkarların bilgi yardımıyla tanımlandığını veya netleştirildiğini savunur, ama egoist çıkar ve kimliklerin rejim yoluyla dönüşüme uğrayabileceğine dair bir öngörüde bulunmaz. Bu konuda özellikle başta Wendt olmak üzere sosyal inşacı kuramcılar farklı bir bakış açısı sunmuşlar ve kimlik ve çıkarların değişime uğrayabilen siyasi ve tarihsel dinamik olgular olduğunu savunmuşlardır. ${ }^{77} \mathrm{Bu}$ bağlamda Wendt, devletler arası işbirliğinin egoist aktörler arasında olabileceğini ve bunu açıklamada da yeni-liberal kuramcıların başarılı olduğunu ifade eder. Buna karşılık, kendisi bir adım daha ileri giderek başlangıçta egoist sebeplerle girişilen bir işbirliğinin zamanla tarafların egoist çıkar ve kimliklerini topluluk çıkar ve kimlikleriyle özdeş duruma getirebildiğini, yani ulusal kimliklerin uluslararası kimliğe dönüşebildiğini savunur. ${ }^{78}$ Böyle bir değişim veya dönüşüm ise rejimlerin daha da kuvvetlenmesi ve etkilerinin artması anlamına gelmektedir. Wendt, uluslararası

72 Ibid., s.178-179. Bu görüşlerin önde gelen temsilcilerinden biri John Ruggie'dir. Bkz., Ruggie, Constructing the World Polity, s.95-98.

73 Hasenclever vd., Theories, s.176-178.

74 Hasenclever vd., “Interests, Power, Knowledge”, s.213-214.

75 Friedrich Kratochwil, Rules, Norms, and Decisions: On the Conditions of Practical and Legal Reasoning in International Relations and Domestic Affairs, Cambridge, Cambridge University Press, 1989, s.254. Hasenclever vd., Theories, s.183-184.

76 Hasenclever vd., "Interests, Power, Knowledge", s.214.

77 Alexander Wendt, "Anarchy is what States Make of it: The Social Construction of Power Politics", International Organization, Cilt 46, No.2, 1992, s.394-395.

78 Wendt, "Anarchy is what States make of it", s.415-418. 
kurumların genelde, uluslararası rejimlerin ise özelde devletlerin egoist kimliklerini diğerlerini dikkate alan (other-regarding) kimliklere dönüştürme potansiyelinin aktörler arasındaki karşılıklı iletişim sayesinde ortaya çıktığını; özneler arası anlayış ve paylaşımların zaman içinde hem devletlerin birbirlerine karşı olan algılarını ve bununla ilişkili olarak kimlik ve çıkarlarını, hem de kurumun kendisini değiştirebildiğini; aktörler ve uluslararası yapı (ki kurumlar ve rejimler bunun bir parçasıdır) arasında diyalektik bir ilişki olduğunu iddia eder. ${ }^{79}$

Literatürde bu ve diğer sosyal inşacı argümanlar ontolojik ve epistemolojik yönlerden değişik inceleme ve eleştirilere tabi tutulmuştur. Rejim kuramı açısından bu kuramla ilgili argümanların spesifik kurum ve rejimlerle ilgili olarak geçerliliğinin, uzun dönemi kapsayan süreç takibi ve söylem analizi gibi yorumsamacı yöntemlerle ortaya konması gerekmektedir. Ayrıca, kimliklerin dönüşebildiğini ortaya koyabilmek kadar, bu dönüşümün rejime özgü özneler-arası paylaşım ve iletişim ile mümkün olduğunu ispat edebilmek de uzun soluklu ve daha kapsamlı çalışmalar gerektirmektedir. Çünkü bu dönüşümde rejim kuramcılarının genel olarak analizlerine dahil etmekten kaçındıkları yerel değişkenler rejimden bağımsız veya rejim ile sinerji halinde önemli rol oynayabilir. Dolayısıyla söz konusu çalışmalar yerel boyutu da dâhil edecek şekilde sürdürülmelidir. ${ }^{80}$

\section{Sentez'e Dair Tartışmalar ve Sonuç}

Rejim kuramı, anlaşıldığı üzere, tek bir değişken üzerine açıklamalarını inşa etmiş bir büyük kuram (grand theory) değildir. Bünyesinde, farklı değişkenler (çıkar, güç ve bilgi) üzerinden genelde uluslararası işbirliğini ve özelde ise kurum ve rejimleri açıklamaya ve/veya anlamaya çalışan kuramsal yaklaşımları barındırmaktadır. ${ }^{81} \mathrm{Bu}$ ilk bakışta bir zayıllık gibi algılanabilse de, her bir bakış açısının aynı olguyu farklı yönlerden inceleyerek zenginlik kattığı da söylenebilir. Zaten zaman içerisinde tartışma, hangi yaklaşımın rejim olgusunu daha iyi açıkladığından, hangi bağlamın (context) hangi değişkenleri daha ön plana çıkardığı veya rejimin hangi boyutunun veya evresinin hangi değişkenler tarafından daha anlaşılır veya açıklanır kılındığı zeminine taşınmış ve bu da sentez çabalarına yol açmıştır.

Sentez tartışmaları en kapsamlı biçimde rejim kuramının Alman akademisyenleri tarafından yürütülmüş ve ilerdeki çalışmalara ışık tutması açısından aşağıda özetlenen bazı kayda değer sonuçlar elde edilmiştir.

İlk olarak, gerçekçi ve yeni-liberal kuramlar arasındaki uluslararası işbirliğine dair tartışma bağlamsal faktörler göz önüne alınmadıkça verimsiz ve sonuçsuz kalmaya mahkûmdur. Çünkü mutlakgöreceli kazanç konusu bağlamdan bağımsız değerlendirilemez; bazı durumlar veya sorun alanları devletlerin göreceli kazançlarını önemsemesine yol açarken, farklı durumlarda bunun yerini mutlak kazanç hesabı alabilir. Dolayısıyla bu baştan tespit edilmeden bu kuramlardan hangisinin özellikle rejim kuruluşunu açıklamada daha geçerli veya başarılı olduğu ortaya konamaz. ${ }^{82}$

79 Ibid., s.422-425.

80 Rejim çalışmalarının Keohane'nin savunduğu sistemik boyuttan yerel boyutun da dahil edildiği daha ileri bir aşamaya evrilmesini savunan örnek bir kavramsallaştırma çalışması için bkz., Michael Zürn, "Bringing the Second Image (Back) In: About the Domestic Sources of Regime Formation”, Rittberger (der.), Regime Theory, s.282-311. Rejim kurallarına uyma konusunu sosyal inşacı ve akılcı varsayımlar çerçevesinden karşılaştırmalı olarak ve yerel değişkenleri de göz önüne alarak inceleyen başarılı bir ülke çalışması için bkz., Jeffrey T. Checkel, "Why Comply? Social Learning and European Identity Change”, International Organization, Cilt 55, No.3, 2001, s.553-588.

81 Hasenclever vd., "Interests, Power, Knowledge”, s.217.

82 Hasenclever vd., "Integrating Theories of International Regimes", s.12-19. 
İkinci olarak, gerçekçi ve yeni-liberal kuramlar gibi akılcı kuramlar ile bilişsel yaklaşımların sentezi konusu karmaşık bir konudur, çünkü bilişsel kuram içerisinde epistemolojik ve ontolojik olarak akılcı kuramlardan ayrışan yaklaşımlar mevcuttur. Sentez daha çok rasyonel kuramların temel varsayımlarını sorgulamayan zayıf bilişselcilerle daha olası gözükmektedir. Bu bağlamda genel olarak iki seçenekten bahsedilebilir: Öncelikle, devlet çıkarlarına ilişkin hedef ve stratejilerin belirsiz olduğu durumlarda zayıf bilişselcilerin üstünde durdukları nedensel veya normatif fikirler bu belirsizliğin giderilmesinde karar alıcılara yol göstererek yardımcı olurlar. Özellikle nedensel, teknik bilgi üretip yayan bilgi topluluklarının bu konuda oynadığı rol işlevseldir; devlet çıkar ve stratejilerinin seçimine veya netleşmesine katkıda bulunarak rejimlerin kurulmasını sağlarlar veya en azından kolaylaştırırlar. Ayrıca, bazı işbirliği durumları "cinsiyetler savaşı"ndakine benzer koordinasyon sorunu içerir; yani aktörler işbirliği yapmaktan daha kazançlı çıkacaklarını bildikleri halde kolektif anlamda benzer optimal sonuçları olan farklı tercihlerin seçiminde zorluk çekerler. Özellikle devletler arasında göreceli güç dağılımının önemli olmadığı, yani güçlerin birbirine yakın olduğu ve söz konusu işbirliği tercihlerinin paylaşımsal sonuçlarının asimetrik olmadığı durumlarda koordinasyon sorununu aşmada gücün yerini fikirler alabilir; koordinasyonun sağlanmasına "odak noktası" oluşturarak yardımcı olabilirler. ${ }^{83}$

Son olarak, kuvvetli bilişselcilerin argümanları ile akılcı kuramlar arasında sentez oluşturmak temel epistemolojik ve ontolojik uyuşmazlıklar sebebiyle pek mümkün gözükmemektedir. Rasyonel kuramlar devlet davranışını genellikle direkt olarak gözlemlenebilen ve ölçülebilen silahlı ve ekonomik güç gibi maddi faktörler yoluyla açıklamaya odaklanırken, kuvvetli bilişselciler devlet davranışını her zaman somut olarak gözlemlenemeyen özneler-arası anlayış, rol, kimlik gibi soyut olgular üzerinden anlamlandırmaya çalışmaktadırlar. Temel hedefleri (akılcıların "açıklamak", bilişselcilerin ise "anlamak") ve ontolojilerindeki farklılaşma bu iki grubun farklı araştırma yöntemleri benimsemesine de yol açmıştır. Her ne kadar iki grupta da söz konusu farklılaşmaların abartılmaması gerektiğini söyleyen ve birbirlerinin yöntemlerini araştırmalarında kullananlar bulunsa da, en azından rejim kuramı bağlamında ciddi bir sentezden söz etmek henüz mümkün gözükmemektedir. ${ }^{84}$

1970’lerden itibaren sistematik ve kapsamlı bir şekilde ele alınan rejim kuramının temelinde yatan "uluslararası sistemin anarşik yapısı altında devletler arası işbirliği mümkün müdür?" sorusu geçerliliğini yıllar içinde yitirmediği gibi, günümüzde önemini daha da artırmıştır. İki kutuplu Soğuk Savaş döneminin sona ermesinden bu yana uluslararası rejimlerin sayısında ve buna bağlı olarak uluslararası ilişkilerin meşrulaşmasında bir artış gözlemlenmektedir. ${ }^{85} \mathrm{Bu}$ bir taraftan devletlerin ve toplumların birbirlerine bağımlılıklarının ve ulus-aşırı sorunların hemen her alanda arttığı küreselleşen dünyada beklenen bir gelişmedir. Diğer taraftan ise, Keohane'nin dikkat çektiği gibi, rejim sayılarındaki artış rejim bütünlüğünü sarsacak şekilde gelişme göstermektedir. Aynı alan veya soruna ilişkin birbirine rakip veya birbirinden kopuk rejim veya rejim benzeri oluşumlar ortaya çıkmaktadır. ${ }^{86}$ Keohane bu durumdan en çok uluslararası güç dağılımındaki değişim veya dalgalanmaları sorumlu tutmakta, özellikle tek kutuplu yeni-liberal düzenle bir şekilde sorunu olan yükselen güçlerin tepkilerini ya alternatif rejimler kurarak ya da mevcut rejimlere meydan okuyarak

83 Ibid., s.25-30.

84 Ibid., s.30-32. Daha derin bir analiz için bkz., Ruggie, Constructing the World Polity, s.85-101.

85 Robert O. Keohane, “Twenty Years of Institutional Liberalism”, International Relations, Cilt 26, No.2, 2012, s.128, 132133.

86 Ibid., s.128-129. 
dile getirdiğini ifade etmektedir. ${ }^{87}$ Yani sorun 1970'lerde görülen sorunla bire bir örtüşmese bile benzeridir: Hegemon gücün düşüşe geçtiği uluslararası sistemde ortaya çıkan meşruiyet sorunu ve bunun uluslararası işbirlikleri ve rejimlere yansıması. Dolayısıyla yukarda ana argümanları verilmeye çalışılan rejim kuramı çoğul içeriği ile bir yandan şimdiki düzeni açıklamak ve anlamlandırmak için seçenekler sunarken, diğer yandan da bu düzenin yeni boyutları (yerel boyutun dış politika yapımına daha çok müdahil olması ile bu boyutun uluslararası siyasette hiç olmadı̆̆ı kadar önem kazanması) ile daha da geliştirilmeyi beklemektedir.

87 Ibid., s.134-135. Özellikle ekonomik alanda giderek artan ikili anlaşmalar imzalama ve bölgeler inşa etme eğilimi de Keohane'nin bahsettiği çok taraflı kurumsallaşmaya bir meydan okuma ve tehdit olarak görülebilir. Bu gelişmeyi ekonomik liberalleşmenin küresel ölçekte gerçekleşmesine engel olarak görenler kadar, bunun Avrupa Birliği örneğinde olduğu gibi giderek daha kapsayıcı olacağını, liberal olmayan ülkelere liberalleşmeyi daha küçük ölçekte öğretip onları çok taraflı kurumların bünyesinde sonradan daha başarılı kılacağını, yerel rekabetçi olmayan oligopol veya kartellerin gücünü kırarak ekonomik verimliliğin önünü açacağını ve gelişmekte olan ülkeler arasında koordinasyon oluşmasına katkıda bulunarak bu ülkelerin Dünya Ticaret Örgütü bünyesinde bireysel olarak elde etmeyi başaramadıkları daha adil ticaret düzenine bu şekilde ulaşabileceklerini iddia edenler de vardır. Konunun ayrıntılı analizi için bkz., Maswood, The South in International Economic Regimes, s. 145-160; Charles Oman, "Globalization, Regionalization, and Inequality", Andrew Hurrell ve Ngaire Woods (der.), Inequality, Globalization, and World Politics, Oxford, Oxford University Press, 1999, s. 38-41, 55-65. 


\section{Kaynakça}

Adler, Emanuel, "The Emergence of Cooperation: National Epistemic Communities and the International Evolution of the Idea of Nuclear Arms Control”, International Organization, Cilt 46, No.1, 1992, s.101-145.

Armstrong, David, “The Nature of Law in an Anarchical Society”, Richard Little ve John Williams (der.), The Anarchical Society in a Globalized World, New York, Palgrave Macmillan, 2006, s.121-140.

Axelrod, Robert ve Robert O. Keohane, "Achieving Cooperation under Anarchy: Strategies and Institutions", World Politics, Cilt 38, No.1, 1985, s.226-254.

Bartelson, Jens, A Genealogy of Sovereignty, Cambridge, Cambridge University Press, 1995.

Booth, Ken ve Wheeler, Nicholas J., The Security Dilemma: Fear, Cooperation and Trust in World Politics, Hampshire, Palgrave Macmillan, 2008.

Checkel, Jeffrey T. "Why Comply? Social Learning and European Identity Change", International Organization, Cilt 55, No 3, 2001, s. 553-588.

Depledge, Joanna, “Against the Grain: The United States and the Global Climate Change Regime”, Global Change, Peace and Security, Cilt 17, No 1, 2005, s. 11-27.

Fierke, K. M, “Constructivism”, Tim Dunne, Milja Kurki ve Steve Smith (der.), International Relations Theories: Discipline and Diversity, Oxford, Oxford University Press, 2007, s.168-184.

Finnemore, Martha ve Kathryn Sikkink, "Taking Stock: The Constructivist Research Program in International Relations and Comparative Politics", Annual Review of Political Science, Cilt 4, 2001, s.391-416.

Franck, Thomas, The Power of Legitimacy Among Nations, Oxford, Oxford University Press, 1990.

Gilpin, Robert, Global Political Economy: Understanding the International Economic Order, Princeton, Princeton University Press, 2001.

Goldstein, Judith ve Robert O. Keohane (der.). Ideas and Foreign Policy: Beliefs, Institutions, and Political Change, Ithaca, Cornell University Press, 1993.

Goldstein, Judith ve Robert O. Keohane, "Ideas and Foreign Policy: An Analytical Framework”, Goldstein, Judith ve Robert O. Keohane (der.). Ideas and Foreign Policy: Beliefs, Institutions, and Political Change, Ithaca, Cornell University Press, 1993, s.3-30.

Grieco, Joseph M., "Anarchy and the Limits of Cooperation: A Realist Critique of the Newest Liberal Institutionalism”, International Organization, Cilt 42, No.3, 1988, s.485-507.

Haas, Peter M., "Banning Chlorofluorocarbons: Epistemic Community Efforts to Protect Stratospheric Zone”, International Organization, Cilt 46, No.1, 1992, s.187-224.

Haggard, Stephen ve Beth A. Simmons, “Theories of International Regimes”, International Organization, Cilt 41, No.3, 1987, s.491-517.

Hall, Ian, “Diplomacy, Anti-diplomacy and International Society”, Richard Little ve John Williams (der.), The Anarchical Society in a Globalized World, New York, Palgrave Macmillan, 2006, s.141-161.

Hasenclever, Andreas, Peter Mayer ve Volker Rittberger, Theories of International Regimes, Cambridge, Cambridge University Press, 1997.

Hasenclever, Andreas Peter Mayer ve Volker Rittberger, "Interests, Power, Knowledge: The Study of International Regimes”, Mershon International Studies Review, Cilt 40, No.2, 1996, s.177-228.

Hasenclever, Andreas, Peter Mayer ve Volker Rittberger, “Integrating Theories of International Regimes”, Review of International Studies, Cilt 26, No.1, 2000, s.3-33.

Hopkins, Raymond F., "Reform in the International Food Aid Regime: The Role of Consensual Knowledge", International Organization, Cilt 46, No.1, 1992, s.225-264.

Hurrell, Andrew, "International Society and the Study of Regimes: A Reflective Approach", Volker Rittberger (der.), Regime Theory and International Relations, Oxford, Clarendon Press, 1995, s.49-72. 
Jackson, Robert, The Global Covenant: Human Conduct in a World of States, Oxford, Oxford University Press, 2003.

James, Alan, "Law and Order in International Society", Alan James (der.), The Bases of International Order: Essays in Honour of C. A. W. Manning, London, Oxford University Press, 1973, s.60-84.

Johnson, Lindsay Emma, Advocates, Experts or Collaborative Epistemic Communities? Defining the Scientific Role of NGOs in International Environmental Negotiations, Yayınlanmamış yüksek lisans tezi, Canada, the University of British Columbia, 2006. https://circle.ubc.ca/bitstream/handle/2429/17646/ubc_2006-0210. pdf? sequence $=1$ (Erişim Tarihi 4 Aralık 2014).

Jönsson, Christer, “Cognitive Factors in Explaining Regime Dynamics”, Volker Rittberger (der.), Regime Theory and International Relations, Oxford, Clarendon Press, s.202-222.

Keohane, Robert O., After Hegemony: Cooperation and Discord in the World Political Economy, Princeton, Princeton University Press, 1984.

Keohane, Robert O., "The Analysis of International Regimes: Towards a European-American Research Programme", Volker Rittberger (der.), Regime Theory and International Relations, Oxford, Clarendon Press, 1995, s.23-45.

Keohane, Robert O., “Twenty Years of Institutional Liberalism”, International Relations, Cilt 26, No.2, 2012, s.125-138.

Krasner, Stephen D. (der.), International Regimes, Ithaca, Cornell University Press, 1983.

Krasner, Stephen D., "Structural Causes and Regime Consequences: Regimes as Intervening Variables", Stephen D. Krasner (der.), International Regimes, Ithaca, Cornell University Press, 1983, s.1-21.

Krasner, Stephen D., "Global Communications and National Power: Life on the Pareto Frontier", World Politics, Cilt 43, No 3, 1991, s. 336-366.

Kratochwil, Friedrich, Rules, Norms, and Decisions: On the Conditions of Practical and Legal Reasoning in International Relations and Domestic Affairs, Cambridge, Cambridge University Press, 1989.

Kratochwil, Friedrich and John Gerard Ruggie, "International Organization: A State of the Art on an Art of the State", International Organization, Cilt 40, No 4, 1986, s. 753-775.

Kratochwil, Friedrich, “The Protagorean Quest: Community, Justice, and the 'Oughts' and 'Musts' of International Politics”, International Journal, Cilt 43, No 2, 1988, s. 205-240.

Kratochwil, Friedrich, “Contract and Regimes: Do Issue Specificity and Variations of Formality Matter?”, Volker Rittberger (der.), Regime Theory and International Relations, Oxford, Clarendon Press, 1995, s. 73-93.

Kydd, Andrew ve Duncan Snidal, “Progress in Game-Theoretical Analysis of International Regimes”, Volker Rittberger (der.), Regime Theory and International Relations, Oxford, Clarendon Press, 1995, s. 112-135.

Little, Richard, "International regimes", John Baylis ve Steve Smith (der.), The Globalization of World Politics: An Introduction to International Relations, Oxford, Oxford University Press, 2001.

March, James G. and Johan P. Olsen, “The Institutional Dynamics of International Political Orders”, International Organization, Cilt 52, No 4, 1998, s. 943-969.

Maswood, S. Javed, The South in International Economic Regimes: Whose Globalization?, New York, Palgrave Macmillan, 2006.

Mearsheimer, John J., “The False Promise of International Institutions”, International Security, Cilt 19, No 3, 1994/1995, s. 5-49.

Oman, Charles, "Globalization, Regionalization, and Inequality", Andrew Hurrell ve Ngaire Woods (der.), Inequality, Globalization, and World Politics, Oxford, Oxford University Press, 1999, s. 36-65.

Puchala, Donald J. and Raymond F. Hopkins, "International Regimes: Lessons from Inductive Analysis", International Organization, Cilt 36, No 2, 1982, s. 245-275.

Reus-Smit, Christian, “Constructivism”, Scott Burchill et al., Theories of International Relations, New York, Palgrave Macmillan, 2005, s. 188-212. 
Rittberger, Volker, "Research on International Regimes in Germany: The Adaptive Internalization of an American Social Science Concept”, Volker Rittberger (der.), Regime Theory and International Relations, Oxford, Clarendon Press, 1995, s. 3-22.

Ruggie, John G., Constructing the World Polity: Essays on International Institutionalization, New York, Routledge, 1998.

Stein, Arthur A., "Coordination and Collaboration: Regimes in an Anarchic World", International Organization, Cilt 36, No 2, 1982, s. 299-324.

Waltz, Kenneth N., Theory of International Politics, Reading, Mass., Addison-Wesley, 1979.

Weldes, Jutta, “Constructing National Interests”, European Journal of International Relations, Cilt 2, No 3, s. 275-318.

Wendt, Alexander, "Anarchy is what States Make of it: The Social Construction of Power Politics", International Organization, Cilt 46, No 2, 1992, s. 391-425.

Wilson, Peter, “The English School's Approach to International Law”, Cornelia Navari (der.), Theorising International Society: English School Methods, New York, Palgrave Macmillan, 2009, s. 167-188.

Young, Oran R., International Cooperation: Building Regimes for Natural Resources and the Environment, Ithaca, Cornell University Press, 1989.

Young, Oran R., "International Regimes: Toward a New Theory of Institutions", World Politics, Cilt 39, No 1, 1986, s. 104-122.

Zehfuss, Maja, Constructivism in International Relations: The Politics of Reality, Cambridge, Cambridge University Press, 2004.

Zürn, Michael, "Bringing the Second Image (Back) In: About the Domestic Sources of Regime Formation”, Volker Rittberger (der.), Regime Theory and International Relations, Oxford, Clarendon Press, s. 282-311. 